\title{
Effect of a novel piperazine compound on cancer cells
}

\author{
So Hyun Jeon and Cha-Gyun Shin*
}

\begin{abstract}
Many drugs have been developed for anticancer chemotherapy. However, more anti-cancer drugs should be developed from potential chemicals to circumvent the disadvantages of existing drugs. Most anti-cancer chemicals induce apoptosis in cancer cells. This study tested the efficiency of a new chemical, the piperazine derivative 1-[2-(Allylthio) benzoyl]-4-(4-methoxyphenyl) piperazine (CB01), on glioblastoma (U87) and cervix cancer (HeLa) cells. CB01 was highly cytotoxic to these cells $\left(\mathrm{IC}_{505}<50 \mathrm{nM}\right)$ and induced the traditional apoptotic symptoms of DNA fragmentation and nuclear condensation at $40 \mathrm{nM}$. Western-blot analysis of the cell lysates revealed that the intracellular apoptotic marker proteins, such as cleaved caspase-3, cytochrome c, and Bax, were highly upregulated in the CB01-treated cells. Furthermore, increased activities of caspase-3 and -9, but not caspase-8, were observed. Therefore, these results suggest that CB01 can act as an anticancer chemotherapeutic by stimulating the intrinsic mitochondrial signaling pathway to induce cytotoxicity and apoptosis in cancer cells.
\end{abstract}

Keywords: Apoptosis, Human cancer cells, Piperazine derivative

\section{Introduction}

Piperazine is a chemical compound in which two of the six carbons facing each other in a hexagon ring were replaced with nitrogen. It is an important compound widely used to develop therapeutics of interest against various diseases due to its availability, simple processing, and high yield [1-3]. Currently, there are several piperazine-based therapeutics, such as anti-depressants $[4,5]$ as well as anti-viral $[6,7]$ anti-inflammatory [8-11], and antioxidant $[12,13]$ agents. Given this high performance of piperazine, several academic and industrial research institutes have developed new piperazine derivatives as therapeutic agents $[14,15]$. Recently, piperazine backbones synthesized via rational drug designing such as piperazine-linked bisanthrapyrazole, 5-hydroxychromenone piperazine, quinazoline linked substitutedpiperazine have shown an excellent performance as anti-cancer drugs $[1,16,17]$. Each of these compounds

\footnotetext{
*Correspondence: cgshin@cau.ac.kr

Department of Systems Biotechnology, Chung-Ang University, Anseong 456-756, Republic of Korea
}

induces apoptosis and suppress the proliferation of cancer cells in erythroleukemic A562 cell line, epidermal cervical cancer, and lung cancer cells, respectively [1, 18]. Apoptosis is a natural and necessary process that maintains homeostasis in diverse organisms. Defects in apoptosis cause immunodeficiency, and genetic and autoimmune problems, eventually leading to cancer. Apoptosis is known to occur via two different pathways-the extrinsic pathway (also called the "death receptor pathway") and the intrinsic pathway (occurs through mitochondria). However, these two pathways are connected, and the factors of one pathway can affect the other. The morphological changes associated with apoptosis in a cell include cell contraction, chromatin condensation, and nuclear and DNA fragmentation. Many currently used chemotherapeutics suppress cancer-cell survival by inducing apoptosis via the two main signaling pathways mentioned above $[19,20]$. This study assessed for the anti-cancer effect of a recently synthesized piperazine compound, 1-[2(Allylthio)-benzoyl]-4-(methoxyphenyl) piperazine (CB01) (Fig. 1). This compound was identified as toxic to non-small cell lung cancer by Dr. SH Hong of 

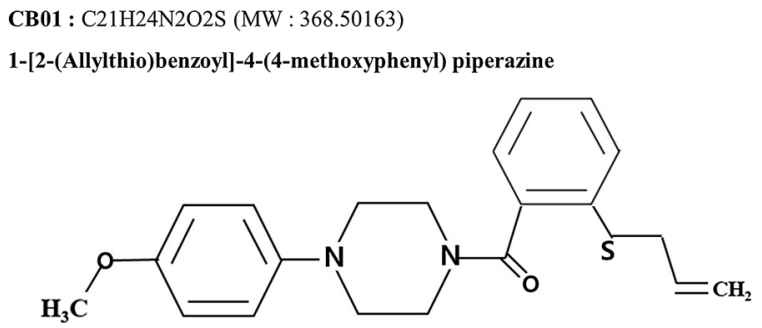

Fig. 1 Chemical structure of 1-[2-(Allylthio)

benzoyl]-4-(4-methoxyphenyl) piperazine (CB01, MW: 368.50163)

the Korea Institute of Radiological Medical Sciences and reported as a potential anticancer compound and was selected from a chemical library obtained from ChemBridge (San Diego, CA, USA).

\section{Materials and methods Reagents}

CB01 was obtained from ChemBridge (San Diego, CA, USA). Each dose of CB01 was diluted with $40 \%$ dimethyl sulfoxide (DMSO). The reagents 3-(4,5-Dimethylthiazol-2-yl)-2,5-diphenyltetrazolium bromide (MTT) and 4',6-diamidino-2-phenylindole (DAPI) were purchased from Sigma-Aldrich (St. Louis, MO, USA). The lactate dehydrogenase (LDH) assay kit was purchased from Dongin Biotech (Soul, Korea). Caspase-3, -8, -9 assay kits, and Z-VAD-FMK, a caspase-3 inhibitor, were purchased from Promega (Madison, WI, USA). Antibodies against caspase-3, Bax, and cytochrome c were bought from Santa Cruz (Santa Cruz, CA, USA).

\section{Cell culture}

U87 and HeLa cells (Korean Cell Line Bank, Seoul, Korea) were grown in Dulbecco's modified Eagle's Medium containing $10 \%$ fetal bovine serum, $2 \mathrm{mM} \mathrm{L}$-glutamine, $100 \mathrm{U} / \mathrm{mL}$ Penicillin, and $100 \mathrm{~g} / \mathrm{mL}$ streptomycin (Sigma-Aldrich, St. Louis, MO, USA). Both cells were cultured in an incubator at $37^{\circ} \mathrm{C}$ with $5 \% \mathrm{CO}_{2}$.

\section{MTT assay}

The MTT assay was performed using a common protocol $[21,22]$. Briefly, cells were seeded in 96-well plates $(50 \mu \mathrm{l}$ of $4 \times 10^{4}$ cells/well). After $4 \mathrm{~h}, 50 \mu \mathrm{l}$ of fresh medium containing CB01 at the indicated dose was added. After $48 \mathrm{~h}$, the MTT solution at $0.1 \mathrm{mg} / \mathrm{mL}$ was added into each well, and the samples were incubated for $4 \mathrm{~h}$. After removing the supernatant, $200 \mu \mathrm{l}$ of $100 \%$ (w/v) DMSO was added to each well, and the samples were incubated at room temperature $\left(25{ }^{\circ} \mathrm{C}\right)$ for $10 \mathrm{~min}$. Finally, the absorbance of the samples at $595 \mathrm{~nm}$ was measured using a microplate reader. The experiment was repeated three times, each in triplicate.

\section{LDH cytotoxicity assay}

The LDH assay was performed using the D-Plustm LDH Cell Cytotoxicity Assay Kit (Dongin LS Biotech, Seoul, Korea). Briefly, $50 \mu \mathrm{l}$ of $2.5 \times 10^{4}$ cells per well were inoculated into a 96-well plate. After $24 \mathrm{~h}$ of culture, $50 \mu \mathrm{l}$ medium with CB01 at the indicated concentration was added to each well. After $48 \mathrm{~h}$, the cells floating in the culture were precipitated via centrifugation at $600 \mathrm{~g}$ for $5 \mathrm{~min}$. The control group was treated with $10 \mu \mathrm{l}$ of lysis buffer in the kit before the centrifugation, and $10 \mu \mathrm{l}$ of the supernatant was transferred to a different well in new 96-well plate. Afterward, $100 \mu \mathrm{l}$ of the LDH reaction mixture, composed of LDH buffer and water-soluble tetrazolium salt (WST) substrate at a 1:50 ratio, was added. The plate was cultured at $20-30{ }^{\circ} \mathrm{C}$ for $30 \mathrm{~min}$, and the absorbance of the samples at $450 \mathrm{~nm}$ was measured using a microplate reader. The experiment was repeated three times, each in triplicate.

\section{Apoptotic DNA-fragmentation assay}

Total DNA with low molecular mass was extracted from the cells as described previously [23]. First, the cells were grown in $60 \mathrm{~mm}$ plates. After $24 \mathrm{~h}, \mathrm{CB} 01$ was administered at 10 or $40 \mathrm{nM}$, and the cells were cultured for $48 \mathrm{~h}$. Afterward, they were washed with phosphate-buffered saline (PBS) and lysed using the ice-cold lysis buffer [0.2\% Triton X-100, $10 \mathrm{mM}$ Tris (pH 7.5), and $10 \mathrm{mM}$ EDTA]. The lysates were incubated on ice for $40 \mathrm{~min}$. Positive control was conducted using $5 \mu \mathrm{M}$ camptothecin (CPT). The lysates were centrifuged at $10,000 \mathrm{~g}$ at $4{ }^{\circ} \mathrm{C}$ for $30 \mathrm{~min}$, and the harvested supernatants were treated with buffered phenol and buffered chloroform-isoamyl alcohol $(24: 1, v / v)$. DNA was ethanol-precipitated and then dissolved in TE buffer [10 mM Tris ( $\mathrm{pH} 7.5)$ with $1 \mathrm{mM}$ EDTA] with $50 \mathrm{ug} / \mathrm{ml}$ RNase A. The DNA samples were analyzed through electrophoresis on $1.2 \%$ agarose gels.

\section{Evaluation of nuclear morphology}

The morphological changes in the nuclei of the cells treated with CB01 were examined through DAPI staining as described before [21]. U87 and HeLa cells were seeded in $35 \mathrm{~mm}$ plates $\left(1.6 \times 10^{5}\right.$ cells $)$ and treated with $40 \mathrm{nM}$ CB01. After $48 \mathrm{~h}$ of culture, the medium was removed, and the cells were washed three times with PBS. Next, they were fixed for $20 \mathrm{~min}$ at $25^{\circ} \mathrm{C}$ with $4 \%$ formaldehyde containing $0.1 \%$ Triton $\mathrm{X}-100$. The cells were then stained for $1 \mathrm{~h}$ at $37^{\circ} \mathrm{C}$ with $300 \mu \mathrm{M}$ DAPI diluted in PBS (1:100, $\mathrm{v} / \mathrm{v})$. The stained cells were observed using a Nikon fluorescence microscope (TE 2000 U: Tokyo, Japan) with ultraviolet (UV) excitation at $300-500 \mathrm{~nm}$. 


\section{Caspase activity assay}

The activities of caspase- $3,-8$, and -9 were examined using caspase-3, -8, -9 colorimetric assay kits (Promega, Biovision, USA) as described before [21, 23]. Cells were treated with $40 \mathrm{nM} \mathrm{CB01}$ for 0,24 , or $48 \mathrm{~h}$. They were then lysed using $50 \mu \mathrm{l}$ lysis buffer, and the supernatants of the lysates were collected by centrifugation at $10,000 \mathrm{~g}$ for $5 \mathrm{~min}$. Subsequently, the total protein concentration of each supernatant was quantified using the Bradford assay. Then, a sample ( $3 \mu \mathrm{l})$ from each lysate was mixed with the $2 \times$ buffer from the assay kit to reach the total volume of $50 \mu \mathrm{l}$, and $4 \mathrm{mM}$ DEVD-pNA substrate from the assay kit was added. After incubating the samples at $37^{\circ} \mathrm{C}$ for $1.5 \mathrm{~h}$, their absorbance at $405 \mathrm{~nm}$ was measured.

\section{Western blotting}

Western blotting was performed as described before [24]. Cells seeded in $60 \mathrm{~mm}$ plates were treated with $40 \mathrm{nM}$ CB01 and incubated for $48 \mathrm{~h}$. The cells were then lysed using Radioimmunoprecipitation Assay buffer [0.1\% SDS, $50 \mathrm{mM}$ Tris- $\mathrm{HCl}$ (pH 7.4), $0.5 \%$ sodium deoxycholate, and $150 \mathrm{mM} \mathrm{NaCl}$. The lysates were centrifuged at $20,000 \mathrm{~g}$ for $15 \mathrm{~min}$ at $4{ }^{\circ} \mathrm{C}$, and the total concentration of each supernatant was measured using the Bradford assay. The proteins in each lysate sample were separated via Sodium Dodecyl Sulfate-Polyacrylamide Gel Electrophoresis (SDS-PAGE) using $12.5 \%$ gel at $130 \mathrm{~V}$ for $1.5 \mathrm{~h}$ and then transferred onto nitrocellulose membranes (GE Healthcare UK Ltd., Hammersmith, UK) at $32 \mathrm{~mA}$ for $1.5 \mathrm{~h}$ by using semi-dry transfer equipment (Hoefer,
Inc., Holliston, MA, USA). The membranes were blocked with the blocking agent $[5 \%(\mathrm{w} / \mathrm{v})$ non-fat dry milk and $0.1 \%(\mathrm{w} / \mathrm{v})$ Tween 20 in PBS] for $2 \mathrm{~h}$ at $4{ }^{\circ} \mathrm{C}$. Lastly, the membranes were probed overnight with monoclonal antibodies against apoptosis-associated proteins [1: 1,000 dilution in PBS with Tween20 (PBST)]. After washing the membranes three times with PBST, they were incubated for $1 \mathrm{~h}$ at $25{ }^{\circ} \mathrm{C}$ with goat anti-mouse IgG conjugated to horseradish peroxidase (1: 5,000 dilution in PBST, Abcam). Afterward, the membranes were washed again with PBST and incubated with the developer kit (Bio FACT, Daejeon, Korea). As an internal control $\beta$-actin was probed with a mouse monoclonal antibody (1: 5000 dilution, Thermo Fisher Scientific, Waltham, MA, USA).

\section{Statistical analysis}

All the data are presented as mean \pm SEM. Statistical significance was assessed using the $t$ test with paired samples; ${ }^{*} p<0.05$, "* $p<0.01$, and ${ }^{* * * *} p<0.001$.

\section{Results \\ CB01 is cytotoxic}

CB01 significantly reduced the viabilities of U87 and HeLa cells, as assessed via the MTT and LDH assays (Fig. 2). For U87 cells, treatment with $1 \mathrm{nM}, 10 \mathrm{nM}$, $100 \mathrm{nM}, 1 \mu \mathrm{M}$, and $10 \mu \mathrm{M}$ CB01 decreased the cell viability to $97.95 \pm 2.9 \%, 81.38 \pm 3.1 \%, 36.21 \pm 3.37 \%$, $18.13 \pm 1.09 \%$, and $13.37 \pm 1.26 \%$, respectively, of the untreated control cells. The same concentrations of CB01 decreased the viability of HeLa cells to $95.08 \pm 3.45 \%$,
$\mathbf{A}$

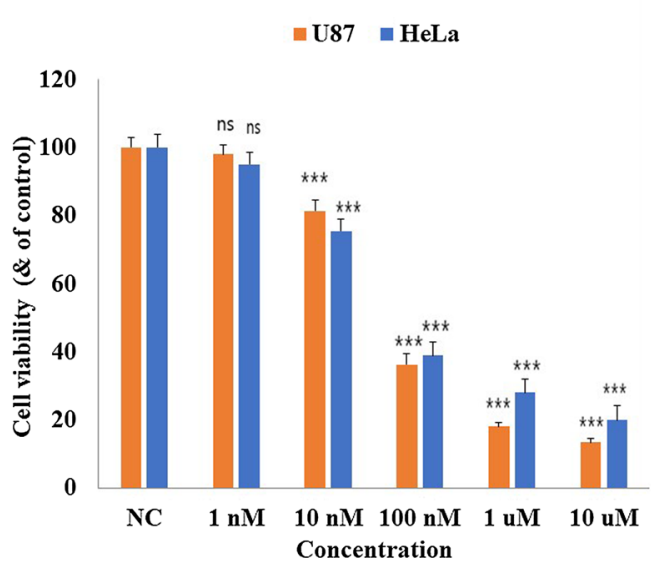

$\mathbf{B}$

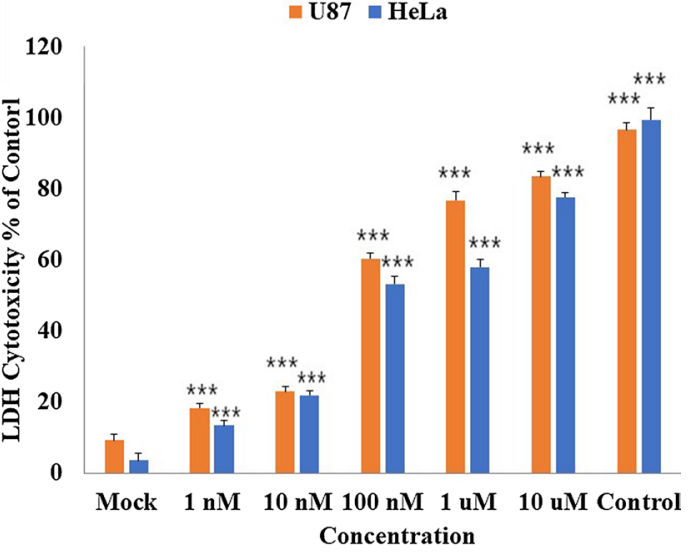

Fig. 2 Cytotoxicity of CB01. A U87 and HeLa cells were incubated in 96-well cell-culture plates with no drug, 1 nM, 10 nM, 100 nM, $1 \mu M$, or $10 \mu \mathrm{M}$ CB01. After $48 \mathrm{~h}$, the cytotoxicity of CB01 was investigated by measuring the number of alive cells via the MTT assay or B by measuring the quantity of lactate dehydrogenase $(\mathrm{LDH})$ released into the medium. The cell viability and quantity of released $\mathrm{LDH}$ are shown as percentages of the control levels (A untreated cells; and $\mathbf{B}$ complete lysis of untreated cells). Based on the dose-response curve, the $I_{50 s}$ of CB01 was estimated at approximately $40 \mathrm{nM}$. All the data are presented as mean \pm SEM. Statistical significance was evaluated using the paired sample $t$ test; $n s=p$ $>0.05,{ }^{*} p<0.05,{ }^{* *} p<0.01$, and ${ }^{* * *} p<0.001$ 
$75.51 \pm 3.38 \%, \quad 38.91 \pm 3.96 \%, \quad 27.98 \pm 3.9 \%, \quad$ and $19.3 \pm 4.13 \%$, respectively, of the untreated control. The $\mathrm{IC}_{50}$ of $\mathrm{CB} 01$ was assessed using dose-response curves and found to be approximately $40 \mathrm{nM}$ in both cells (Fig. 2A). LDH is a cytoplasmic enzyme that exists in various cells and is released into the medium when the cell membrane is disrupted [25]. The LDH assay is a simple colorimetric method used to determine cytotoxicity accurately. For U87 cells, the LDHbased cytotoxicity levels of the cells treated with $0 \mathrm{nM}$ (mock), $1 \mathrm{nM}, 10 \mathrm{nM}, 100 \mathrm{nM}, 1 \mu \mathrm{M}$, and $10 \mu \mathrm{M}$ CB01 were $25.32 \pm 1.82 \%, \quad 33.08 \pm 1.31 \%, \quad 37.06 \pm 1.43 \%$, $68.74 \pm 1.55 \%, 82.70 \pm 2.28 \%$, and $88.36 \pm 1.58 \%$, respectively, of the control, which was lysed untreated cells. In addition, the LDH-based cytotoxicity levels of HeLa cells were $19.62 \pm 1.89 \%, 27.77 \pm 1.48 \%, 34.89 \pm 1.41 \%$, $61.38 \pm 2.22 \%, 65.44 \pm 2.09 \%$, and $81.61 \pm 1.17 \%$, respectively (Fig. 2B). As shown in Fig. 2, the LDH-assay results are in line with the MTT-assay results. Overall, these results show that CB01 is highly cytotoxic to U87 and HeLa cells.

\section{CB01 induces the apoptotic symptoms of DNA and nuclear fragmentation}

To determine whether the cytotoxicities observed in Fig. 2 are related to apoptosis, CB01-treated cells were evaluated for DNA and nuclear fragmentation, which are indicators of apoptosis. Specifically, DNA fragmentation was observed in HeLa and U87 cells treated with $40 \mathrm{nM}$ CB01 (Fig. 3A). In this experiment, $5 \mu \mathrm{M}$ camptothecin (CPT), which is an alkaloid that is a wellknown drug that causes apoptosis by selectively inhibiting DNA topoisomerase type 1, was used as a positive control [26]. CB01 induced DNA fragmentation very clearly at $40 \mathrm{nM}$. In addition, DAPI staining revealed that CB01 caused nuclear fragmentation in U87 and HeLa cells (Fig. 3B).

\section{CB01 upregulates the major apoptotic proteins}

Caspases are known as the core enzymes of apoptosis [27]. The levels of apoptotic markers in CB01treated cells were assessed to determine whether the CB01-induced cytotoxicity is associated with caspases. Through western blot analysis, the activities of apoptotic marker proteins in cells treated with $40 \mathrm{nM}$ CB01 for $48 \mathrm{~h}$ were assessed. The three proteins play an important role in initiating apoptosis. The activated Bax induces permeability in the mitochondrial outer membrane. The cytochrome c was released from mitochondria. The caspase proteins which are key enzymes for apoptosis, were activated. The activities of apoptosis core proteins, such as cytochrome c, Bax, and cleaved caspase-3, which is active form, were observed in the cells treated with $40 \mathrm{nM} \mathrm{CB01}$ for $48 \mathrm{~h}$ (Fig. 4). These data demonstrate that CB01 causes cytotoxicity through induction of apoptosis.

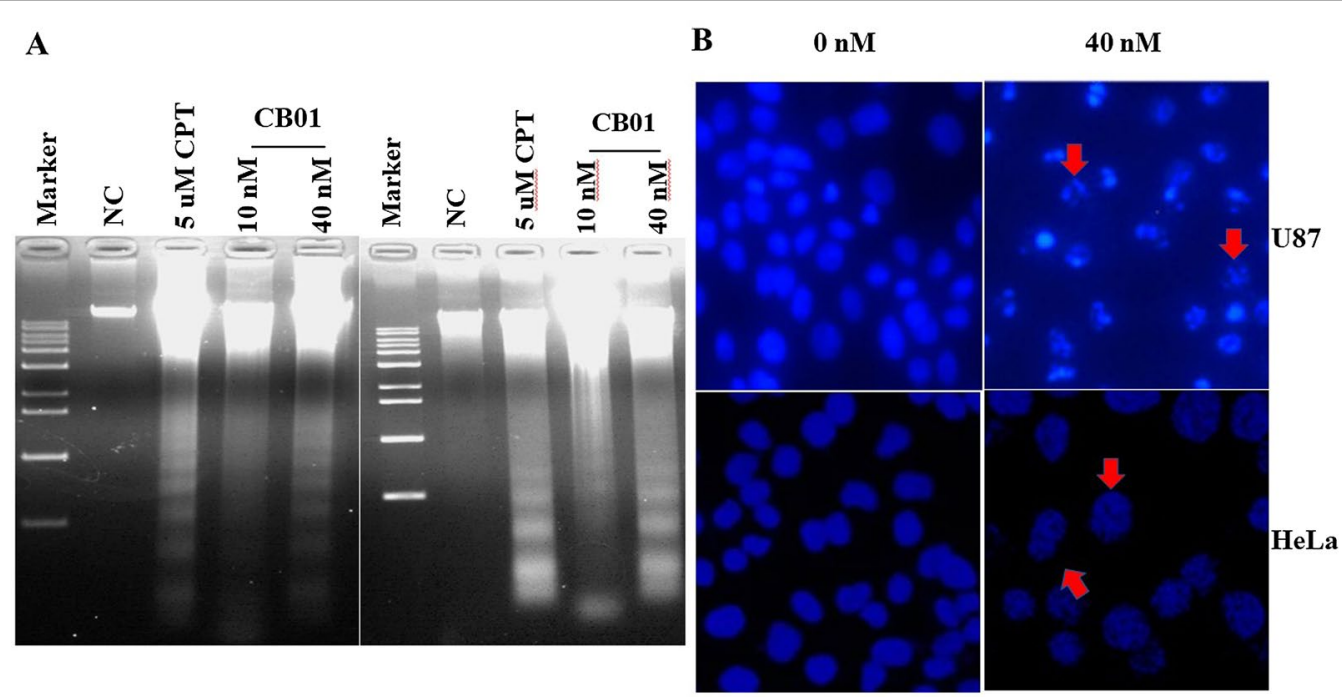

Fig. 3 DNA fragmentation and nuclear-morphology changes induced by CB01. A DNA fragmentation. U87 and HeLa cells were cultured with 10 and $40 \mathrm{nM} \mathrm{CB01}$, respectively, in $60 \mathrm{~mm}$ culture plates. After $48 \mathrm{~h}$, the cells were lysed, and the supernatants of the lysates were collected and subjected to phenol-chloroform extraction. DNA was harvested by ethanol-precipitation and then treated with RNase A for $2 \mathrm{~h}$. The positive control for the DNA fragmentation was cells treated with $5 \mu \mathrm{M}$ camptothecin; a $1 \mathrm{~kb}$ DNA size marker was used. B Evaluation of nuclear morphology. U87 and HeLa cells were grown in $35 \mathrm{~mm}$ culture plates with 0 or $40 \mathrm{nM}$ CB01. The nuclei of the cells were stained with DAPI 


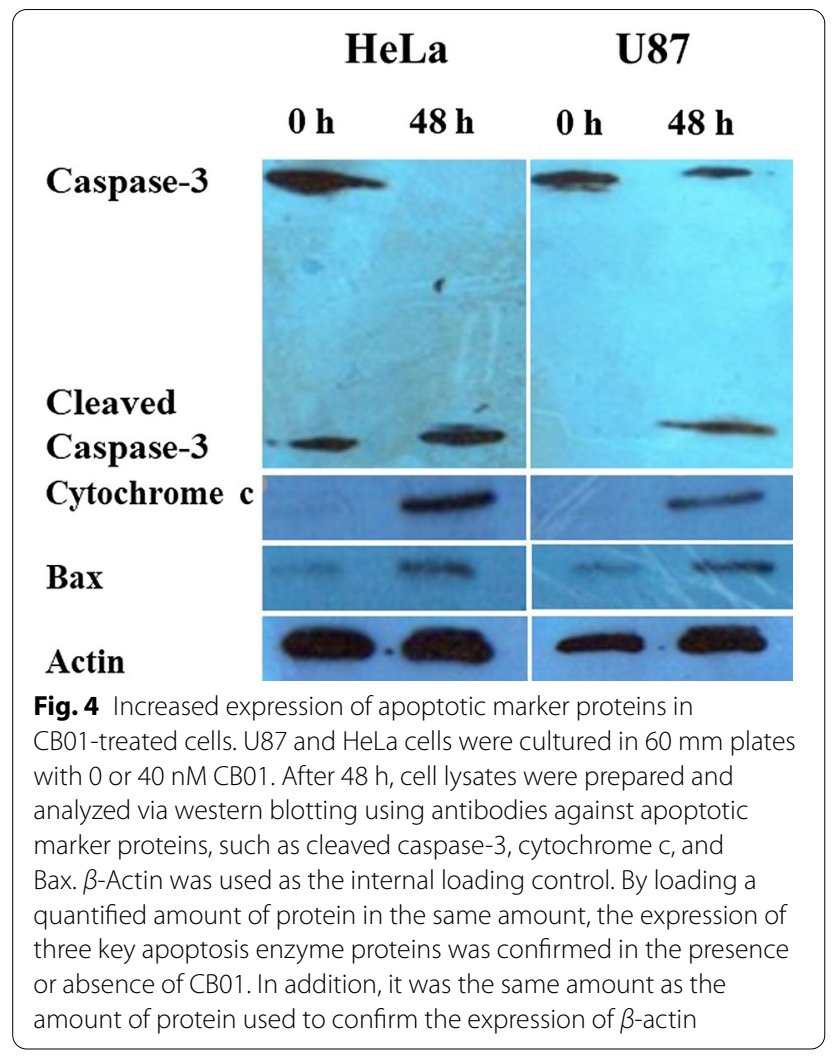

\section{The caspase inhibitor Z-VAD-FMK suppressed the $\mathrm{CB} 01$-induced apoptosis}

The two known apoptosis pathways commonly lead to the activation of caspase- 3 , and thus caspase- 3 activation serves as direct evidence of apoptosis [23]. We observed significantly elevated caspase- 3 activities in the lysates of CB01-treated U87 and HeLa cells, compared with the levels in the untreated controls. In addition, these CB01induced increases in caspase- 3 activities were suppressed by the pan-caspase inhibitor Z-VAD-FMK, which irreversibly binds to the cleavage site of a caspase, whereby the caspase cannot be cleaved to be activated [28]. Collectively, our results suggest that CB01 selectively induces the activation of caspase-3 in U87 and HeLa cells (Fig. 5).

\section{CB01 induces apoptosis via the intrinsic pathway}

Apoptosis occurs through either an extrinsic or intrinsic pathway. The extrinsic pathway is activated through ligand-binding interactions on extracellular surface receptors, whereas the intrinsic pathway, also called the mitochondrial pathway, is activated through intracellular signals within the mitochondrial inter-membrane space [29]. The caspase- $3,-8$, and -9 activities were investigated using a colorimetric assay to determine which apoptotic pathway was induced in CB01-treated cells. The activities

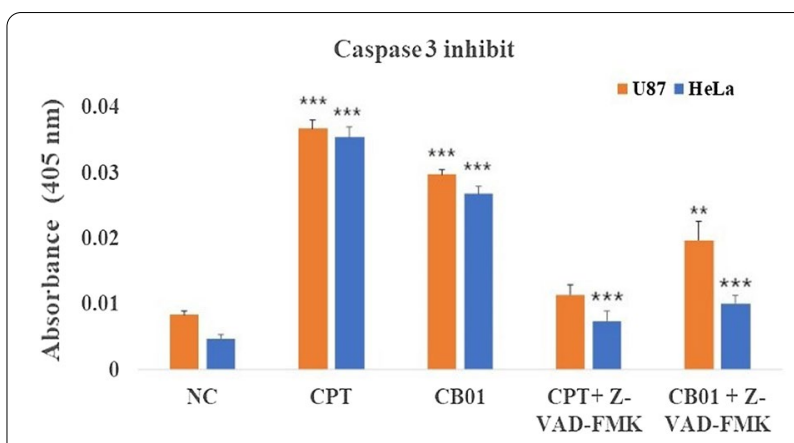

Fig. 5 Suppression of CB01-induced caspase-3 activity by the caspase-3 inhibitor Z-VAD-FMK. U87 and HeLa cells were co-treated with $50 \mu \mathrm{M} Z$ Z-VAD-FMK and $40 \mathrm{nM}$ CB01 or $5 \mu \mathrm{M}$ CPT for $48 \mathrm{~h}$. Then, cell lysates were prepared, and their total protein concentrations were quantitated using the Bradford Assay. The caspase-3 activity in each lysate was assessed using a fluorescent assay kit

of caspase- 3 and -9 in cells treated with $40 \mathrm{nM}$ CB01 increased over time; however, the caspase- 8 activities in these cells were unaffected (Fig. 6). Thus, CB01 appears to cause apoptosis via the intrinsic pathway.

\section{Discussion}

Several anticancer drugs are currently used in chemotherapy. Chemotherapy has the benefit of being applicable irrespective of the cancer stage. Over the years, tremendous medical advances have been made in comprehending cancer biology and devising targeted chemotherapy [30]. Novel remedial chemicals and access methods with powerful effects on tumor or healthy tissues are continuously being adopted in clinics [31]. Although the efficacy of existing chemotherapeutics is not without controversy, there is a growing consensus that their anti-cancer effects are partly due to their abilities to induce apoptosis. The clinical use of these drugs is time-consuming and expensive, thus economical, and efficient anti-cancer drugs are needed [32]. Piperazine derivatives are a class of chemical compounds that contain piperazine as the key functional group and possess many pharmacological properties. Several studies on many piperazine derivatives have been reported, and the results of several relevant clinical trials are encouraging $[4,6,8]$. As the piperazine skeleton can easily be combined with various structures, whereby promising economical anticancer drugs may be developed in the future [1]. A recent study found that the synthesized piperazine derivative CB01 is effective in killing U87 and HeLa cells by inducing apoptosis according to mitochondrial changes. This study is the first to explore, discover, and reveal the mechanism of action of CB01, a new anticancer substance, and is expected 

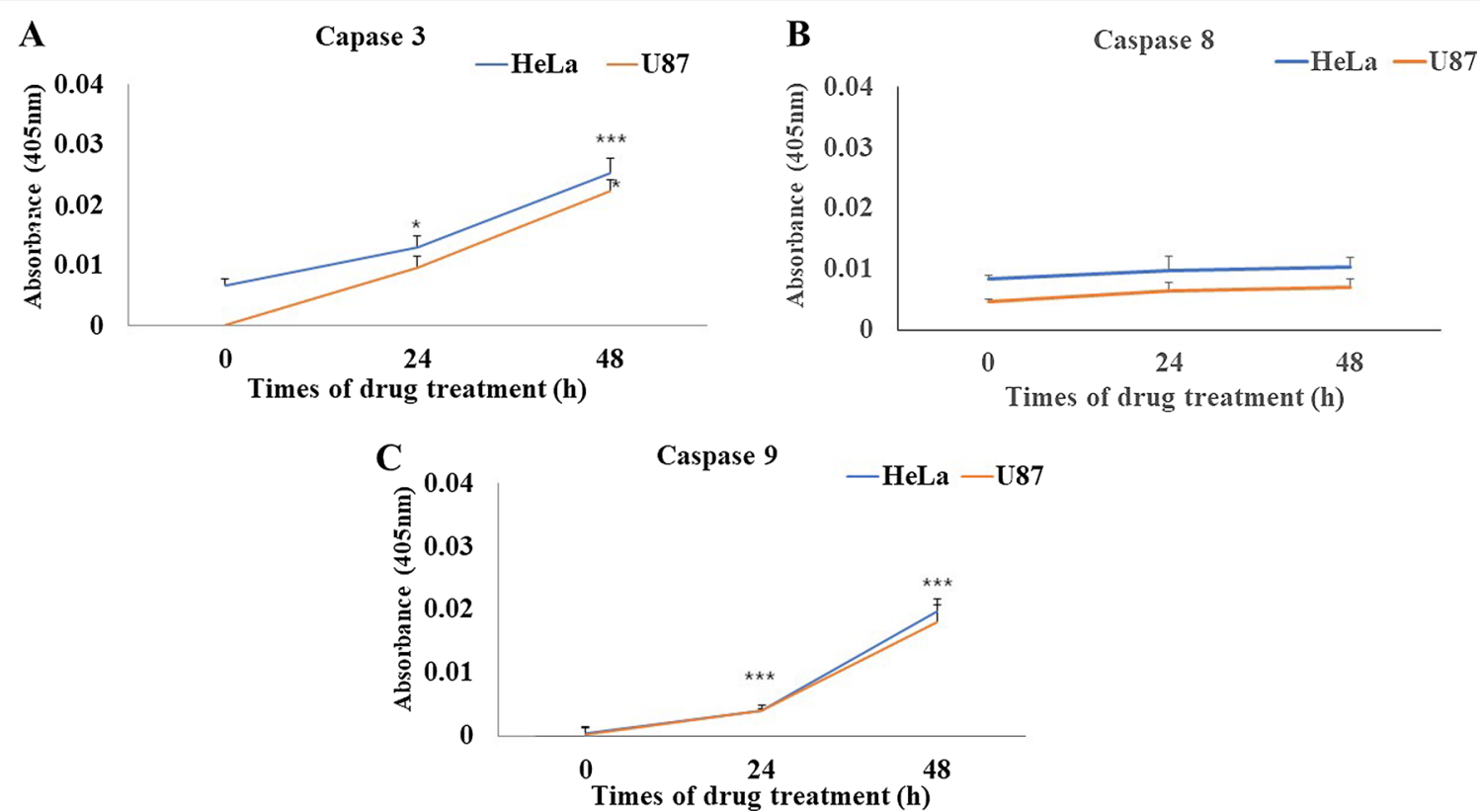

Fig. 6 Comparison of the caspase-3, -8, and -9 activities. U87 and HeLa cells were treated with $40 \mathrm{nM}$ CB01. Cell lysates were prepared after $24 \mathrm{~h}$ or $48 \mathrm{~h}$, and their total protein concentrations were quantitated using the Bradford Assay. The caspase-3, -8, and -9 activities of each lysate were measured using fluorescent assay kits. The samples were incubated at $37^{\circ} \mathrm{C}$ for $2 \mathrm{~h}$, and their absorbance at $405 \mathrm{~nm}$ was measured. All the data are expressed as mean \pm SEM. Statistical significance was evaluated using the paired sample $t$ test; $\mathrm{ns}=p>0.05,{ }^{*} p<0.05$, ${ }^{* *} p<0.01$, and ${ }^{* * *} p<0.001$

to greatly contribute to the discovery of new anticancer substances and the promotion of cancer research in Korea. Furthermore, it is expected that a new cancer treatment strategy will be established based on the mechanism of DNA damage response by CB01. The strategy of administering CB01 to radiation therapy and chemotherapy, which are treatments that induce DNA damage, can increase the efficiency of chemotherapy. Given the modifiable of piperazine, it is expected that the basic structural properties of piperazine can be used to devise a supplementary alternative, for the treatment of solid tumors, particularly in the breast, pancreas, colon, and lung.

\section{Acknowledgements}

This work was supported by a grant from the National Research Foundation of Korea (NRF) funded by the Korean government (NRF-2018R1D1A1A01059592) to Cha-Gyun Shin, and by the Chung-Ang University Graduate Research Scholarship in 2020 to So-Hyun Jeon.

\section{Authors' contributions}

Objectification, survey, data analysis and drafting, data collection, and visualization, were all under SHJ, and revision of manuscripts, project management and funding were done by C-GS. All authors have read and approved the final manuscript.

\section{Declarations}

\section{Competing interests}

The author of the paper does not declare a competitive fiscal gain.

Received: 10 August 2021 Accepted: 7 November 2021

Published online: 17 November 2021

\section{References}

1. Sharma A, Wakode S, Fayaz F, Khasimbi S, Pottoo FH, Kaur A (2020) An overview of piperazine scaffold as promising nucleus for different therapeutic targets. Curr Pharm Des 26:4373-4385

2. Yousefi MR, Goli-Jolodar O, Shirini F (2018) Piperazine: an excellent catalyst for the synthesis of 2-amino-3-cyano-4H-pyrans derivatives in aqueous medium. Bioorg Chem 81:326-333

3. Azema J, Guidetti B, Dewelle J, Calve BL, Mijatovic T, Korolyov A, Vaysse J, Malet-Martino M, Martino R, Kiss R (2009) 7-[(4-Substituted)) piperazine1-yl] derivatives of ciprofloxacin: synthesis and in vitro biological evaluation as potential antitumor agents. Bioorg Med Chem 17:5396-5407

4. Gu ZS, Xiao Y, Zhang QW, Li JQ (2017) Synthesis and antidepressant activity of a series of arylalkanol and aralkyl piperazine derivatives targeting SSRI/5-HT 1 A $/ 5-H T_{7}$. Bioorg Med Chem Lett 27:5420-5423

5. Silva DM, Sanz G, Vaz BG, Carvalho FS, Liao LM, Oliveira DR, Moreira LKS, Cardoso CS, Brito AF, Silva DPB, Rocha FF, Santana LGC, Galdino PM, Costa EA, Menegatti R (2018) Tert-butyl4-[(1-phenyl-1H-pyrazol-4-yl) methyl] piperazine-1-carboxylate $\left(\mathrm{LQFM}_{104}\right)$-new piperazine derivative with antianxiety and antidepressant-like effects: putative role of serotonergic system. Biomed Pharmacother 103:546-552 
6. Dou D, He G, Mandadapu SR, Aravapalli S, Kim Y, Chang KO, Groutas WC (2012) Inhibition of noroviruses by piperazine derivatives. Bioorg Med Chem Lett 22:377-379

7. Bassetto M, Leyssen P, Neyts J, Yerukhimovich MM, Frick DN, CourtneySmith M, Brancale A (2017) In silico identification, design and synthesis of novel piperazine-based antiviral agents targeting the hepatitis $C$ virus helicase. Eur J Med Chem 125:1115-1131

8. Jain A, Chaudhary J, Khaira H, Chopra B, Dhingra A (2021) Piperazine: a promising scaffold with analgesic and anti-inflammatory potential. Drug Res 71:62-72

9. Wei ZY, Chi KQ, Wang KS, Wu J, Liu LP, Piao HR (2018) Design, synthesis, evaluation, and molecular docking of ursolic acid derivatives containing a nitrogen heterocycle as anti-inflammatory agents. Bioorg Med Chem Lett 28:1797-1803

10. Batista DC, Silva DPB, Florentino IF, Cardoso CS, Goncalves MP, Valadares MC, Sanz G, Vaz BG, Costa EA, Menegatti R (2018) An- inflammatory effect of a new piperazine derivative: (4-methylpiperazin-1-yl) (1-phenyl1H-pyrazol-4-yl) methanone. Inflammopharmacology 26:217-226

11. Karthik CS, Manukumar HM, Ananda AP, Nagashree S, Rakesh KP, Mallesha L, Qin HL, Umesha S, Mallu P, Krishnamurthy NB (2018) Synthesis of novel benzodioxane midst piperazine moiety decorated chitosan silver nanoparticle against biohazard pathogens and as potential anti-inflammatory candidate: a molecular docking studies. Int J Biol Macromol 108:489-502

12. Berczynski P, Kladna A, Dundar OB, Murat HN, Sari E, Kruk I, Aboul-Enein HY (2020) Preparation and in vitro antioxidant activity of some novel flavone analogues bearing piperazine moiety. Bioorg Chem 95:103513

13. Patel RV, Mistry B, Syed R, Rathi AK, Lee YJ, Sung JS, Shinf HS, Keum YS (2016) Chrysin-piperazine conjugates as antioxidant and anticancer agents. Eur J Pharm Sci 88:166-177

14. Brito AF, Moreira LKS, Menegatti R, Costa EA (2018) Piperazine derivatives with central pharmacological activity used as therapeutic tools. Fundam Clin Pharmacol 33:13-24

15. Abdelsayed S, Ha Duong NT, Bureau C, Michel PP, Hirsch EC, El Hage Chahine JM, Serradji N (2015) Piperazine derivatives as iron chelators: a potential application in neurobiology. Biometals 28:1043-1061

16. Gao H, Zhang X, Pu XJ, Zheng X, Liu B, Rao GX, Wan CP, Mao ZW (2019) 2-benzoylbenzofuran derivatives possessing piperazine liker as anticancer agents. Bioorg Med Chem Lett 29:806-810

17. Gurdal EE, Buclulgan E, Durmaz I, Cetin-Atalay R, Yarim M (2015) Synthesis and anticancer activity evaluation of some benzothiazole-piperazine derivatives. Anticancer Agents Med Chem 15:382-389
18. Rathi AK, Syed R, Shin HS, Patel RV (2016) Piperazine derivatives for therapeutic use: a patent review (2010-present). Expert Opin Ther Pat 26:777-797

19. Elmore S (2007) Apoptosis: a review of programmed cell death. Toxicol Pathol 35:495-516

20. Fulda S, Debatin KM (2006) Extrinsic versus intrinsic apoptosis pathways in anticancer chemotherapy. Oncogene 25:4798-4811

21. Alamgir Hossain MD, Wongsrikaew N, Yoo GW, Han JH, Shin CG (2012) Cytotoxic effects of polymethoxyflavones isolated from Kaempferia parviflora. J Korean Soc Appl Biol Chem 55:471-476

22. Lee GE, Shin CG (2018) Influence of pretreatment with immunosuppressive drugs on viral proliferation. J Microbiol Biotechnol 28:1716-1722

23. Hyun U, Lee DH, Lee C, Shin CG (2009) Apoptosis induced by enniatins $\mathrm{H}$ and MK 1688 isolated from Fusarium oxysporum FB1501. Toxicon 53:723-728

24. Jensen EC (2012) The basics of western blotting. Anat Rec 295:369-371

25. Parhamifar L, Andersen H, Moghimi SM (2019) Lactate dehydrogenase assay for assessment of polycation cytotoxicity. Methods Mol Biol 1943:291-299

26. Liehr JG, Harris NJ, Mendoza J, Ahmed AE, Giovanella BC (2006) Pharmacology of camptothecin esters. Ann NY Acad Sci 922:216-223

27. Kuranaga E (2012) Beyond apoptosis: caspase regulatory mechanisms and functions in vivo. Genes Cells 17:83-97

28. Moretti L, Kim KW, Jung DK, Willey CD, Lu B (2009) Radiosensitization of solid tumors by z-vad, a pan-caspase inhibitor. Mol Cancer Ther 8:1270-1279

29. Golder S, Khaniani MS, Derakhshan SM, Baradaran B (2015) Molecular medhanisms of apoptosis and roles in cancer development and treatment. Asian Pac J Cancer Prev 16:2129-2144

30. Wiemann MC, Calabresi P (1983) Principles of current cancer chemotherapy. Compr Ther 9:46-52

31. Reyes-Farias M, Carrasco-Pozo C (2019) The anti-cancer effect of quercetin: molecular implications in cancer metabolism. Int J Mol Sci 20:3177

32. Chen M, Hu J, Tang X, Zhu Q (2019) Piperazine as an inexpensive and efficient ligand for pd-catalyzed homocoupling reactions to synthesize bipyridines and their analogues. Curr Org Synth 16:173-180

\section{Publisher's Note}

Springer Nature remains neutral with regard to jurisdictional claims in published maps and institutional affiliations.

\section{Submit your manuscript to a SpringerOpen ${ }^{\circ}$ journal and benefit from:}

- Convenient online submission

- Rigorous peer review

- Open access: articles freely available online

- High visibility within the field

- Retaining the copyright to your article

Submit your next manuscript at $\boldsymbol{\nabla}$ springeropen.com 